\title{
AN ARGHAEOLOGICAL STUDY OF THE BATTLE OF THE BOYNE AT OLDBRIDGE, CO MEATH
}

\author{
CONOR BRADY, EMMET BYRNES, GABRIEL COONEY \& \\ AIDAN O'SULLIVAN
}

\begin{abstract}
This paper outlines the results of a pilot archaeological study carried out on the Oldbridge Estate, Co. Meath, Ireland, in advance of its development for the presentation of the events of the Battle of the Boyne which was fought by the forces of King William III and James II on 1st July 1690. Archival research including the examination of museum collections, cartographic sources, contemporary artistic depictions of the battle and recent aerial photographic coverages was followed up by the use of a range of archaeological techniques including systematic surface collection survey, soil phosphate analysis, magnetic gradiometry, metal detecting and limited test excavation. Additionally, marine geophysics equipment was used to profile the character of the River Boyne, especially in the area of the main crossings. The study revealed important new evidence including the establishment of the location of Oldbridge village, a pivotal feature in the conduct of the battle, the confirmation of the location of the first engagement on the day of the battle and the first systematically recovered artefacts from the battlefield.
\end{abstract}

\section{Introduction}

Although fought over three centuries ago, and less decisive then the much more intense Battle of Aughrim, the Battle of the Boyne and its landscape are central to the definition of Ulster Protestants' culture and identity, especially those who are also members of the Orange Order. While the battle was fought on 1st July, the victory of William III over James II is now celebrated annually on 12th July ${ }^{1}$ following the reform of the calendar in 1752 . The event is commemorated annually by the Orange Order and the wider Protestant Unionist community and represents the focus of the summer marching season in the six counties of Northern Ireland. Ulster Protestant culture is described in a number of publications (see for example Kinealy 2004; Haddick-Flynn 1999; Whelan 1996; Smyth 1995; Long 1978; Delwar, Brown \& Long 1969).

Because of the cross-border significance of the battlefield in a climate of increased toleration, acceptance and understanding of the traditions of both

1 The Julian Calendar was abolished in 1752 and was replaced by the Gregorian Calendar which introduced the innovation of the leap year to retain accuracy. This caused the discrepancy between the two systems.

(C) Koninklijke Brill NV, Leiden, 2007

DOI: $10.1163 / 157407807 X 257368$ 
communities in Northern Ireland, and as a direct consequence of the 1998 Good Friday agreement in 2000 the Irish Government purchased the Oldbridge Estate, Co Meath, a portion of the battlefield which saw much of the most intensive activity on the day of the battle, with the plan of developing the site as part of the shared heritage of all communities on the island of Ireland. To provide baseline data for the management and presentation of the site, Dúchas, The Heritage Service ${ }^{2}$ commissioned members of the School of Archaeology, University College Dublin to undertake a pilot survey of the estate with particular focus on the archaeology of the battle (Cooney et al. 2001; 2002).

\section{Historical Background}

The background to the battle has much more to do with the international affairs of the time than those of Ireland, the country only having been chosen by James II as it was largely Catholic and loyal to him as king of England. Many European leaders had an interest in the outcome of the battle which was a key engagement in the Williamite Campaign.

In 1688 William III was invited to invade England by prominent Protestants there who feared a Catholic succession to the English throne following the birth of a son to James II, an invitation referred to as the 'Glorious Revolution'. James fled to Ireland where he could rely on Catholic support, leaving William's acceptance of the throne unopposed. William sent an army to Ireland to quell support for James and to defeat his forces. Eventually, he had to take command personally, leading to the Battle of the Boyne on 1st July 1690 (old calendar). James II had backing from Louis XIV of France who wanted to create a Catholic power-bloc to dominate Europe. Many other European leaders feared Louis' dominance and as a result many supported William, including Catholic leaders like the king of Spain, the elector of Bavaria and even Pope Innocent XI until his death in 1689 (Murtagh 2006; McNally 2005; Lenihan 2003; Gibbs 1990; Miller 1990; McGuire 1990).

In the immediate run up to the battle, William had a force of 36,000 under his command, made up of Dutch, English, Danes, Huguenots and Ulster Protestants. The continental soldiers were the most experienced of these and most of his generals were drawn from these groups. The Jacobite force was made up of about 25,000 men, most of whom, including the generals and

2 Dúchas, The Heritage Service was disbanded in 2003 and responsibility for the project now lies with the Office of Public Works. 
officers, were relatively inexperienced Irish soldiers, and many had been only recently recruited. A contingent of French soldiers sent by Louis to assist James numbering 6,500, were more experienced but in the event played no major role in the battle on the day (Murtagh 2006: 17-18).

James II chose the Boyne as the best place to do battle with William as he advanced southwards to Dublin as the river formed a major natural barrier that could be used to some strategic advantage. There were limited opportunities for the Williamites to cross the river - there were bridges at Drogheda $4 \mathrm{~km}$ to the east and at Slane $8 \mathrm{~km}$ to the west, while there were also a number of fords in between. James installed a garrison within the walls of the town of Drogheda protecting the bridge there and on the day before the battle he had the bridge upstream at Slane broken so the Williamites could only cross by one of the fords.

The Jacobites encamped on the southern side of the river between Rathmullan and Donore Hill where James set up his headquarters. The Williamite forces encamped along the Tullyallen ridge with their headquarters at Mellifont Abbey. On the day of the battle, 1 July 1690, William sent 10,000 of his total force of 36,000 westwards under Count Meinard Schomberg to cross the river at Rossnaree ford. James believed that this was the main attack and sent 17,000 of his force of 25,000 along with most of his artillery upstream along the southern bank of the river to engage them. The Williamite diversionary force crossed the river at Rossnaree and the two armies ended up facing each other across a steep ravine - the valley of the Lougher Riverand did not engage each other for the duration of the battle. The main crossings took place at Oldbridge and, after a short period of relatively intense engagement here, hugely outnumbered, the Jacobite forces fell back towards the Hill of Donore and Platin and ultimately to Duleek where the Jacobite army filed across a single narrow bridge spanning the River Nanny and then retreated towards Dublin (Murtagh 2006: 35-57; McNally 2005: 58-85; Lenihan 2003: 147-207; Stout 2002: 115; Childs 1996: 201; Beresford Ellis 1976: 76-121).

\section{The Physical Setting}

The battlefield itself is thus quite extensive, stretching from Tullyallen in the north to Duleek $9 \mathrm{~km}$ away to the south and from the ford at Rossnaree in the west to the outskirts of Drogheda another $8 \mathrm{~km}$ away to the east. Most of the actual fighting was concentrated on the south bank in Oldbridge, Rathmullan and Sheephouse townlands with further incidents at the Hill of Donore and also at Platin (Figure 1). 


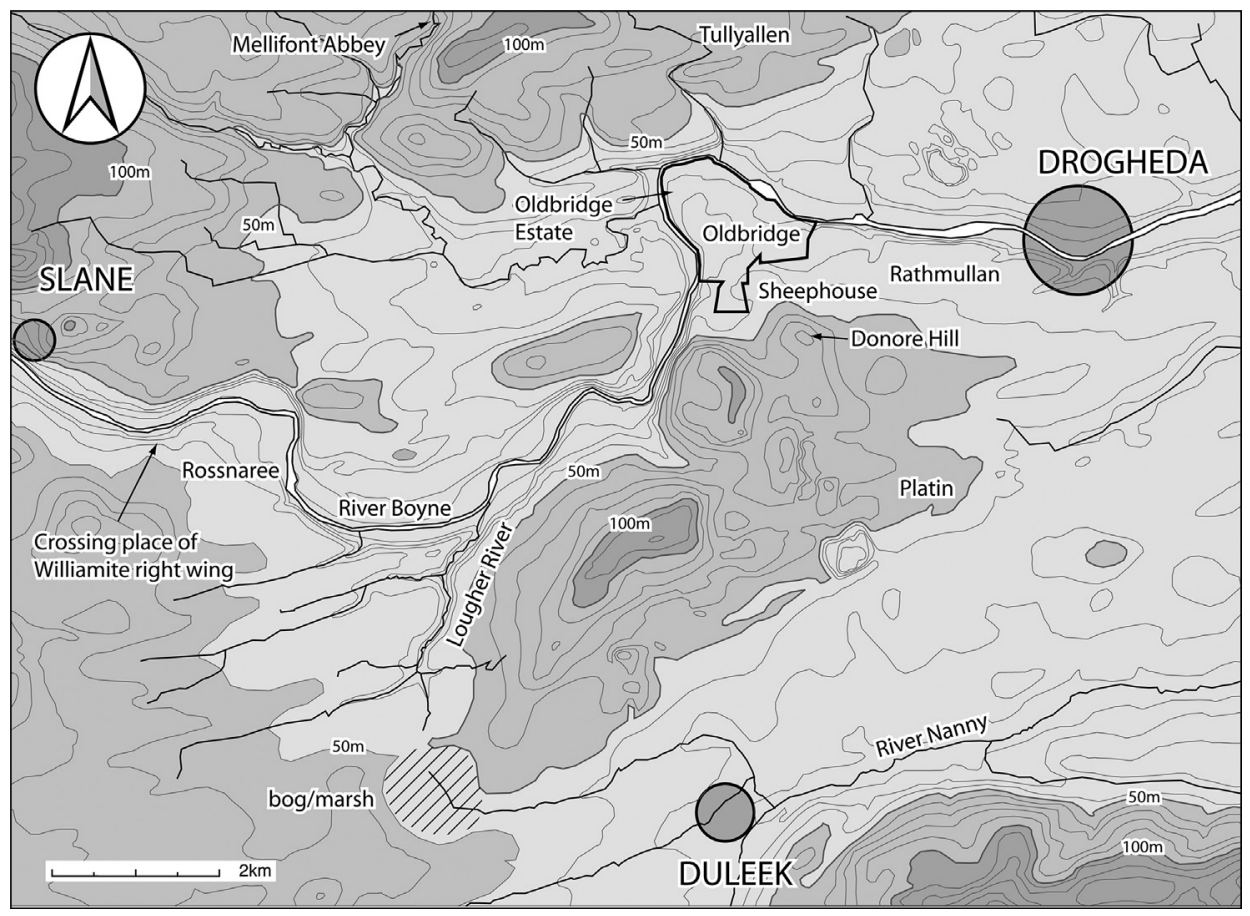

Fig. 1. The landscape of the Battle of the Boyne.

The battlefield is located within the valley of the River Boyne and is overlooked on both the northern and southern sides by high ground. The land slopes steeply on the northern side of the river between Tullyallen and Oldbridge, while on the southern side there is a more gradual series of terraces stepping up from river level to the higher ground around the Hill of Donore. To the west at Sheephouse, the valley side slopes steeply to the river's edge on the southern side of the river and the same is the case to the east at Rathmullan, making Oldbridge an ideal location for a major crossing (Meehan and Warren 1999: 4-5; Stout 2002: 114, fig. 8).

The former Oldbridge Estate can thus be seen as forming a key part of the larger landscape area involved in the events of the day and this was the focus of the study. Oldbridge Estate comprises 500 acres (ca. 200 hectares) of prime agricultural land. Oldbridge House, built around 1750 (Bence-Jones 1978: 228), is located above a sharp bend in the river and is situated at the western end of a designed parkland landscape. There is a gate lodge at the eastern end of an avenue close to the ford over the River Boyne which fea- 
tured prominently in the events on the day of the battle. The Obelisk Bridge, named after a monument erected in the 18th century commemorating the battle and blown up in 1923, now spans the river a short distance upstream of the ford. There is also a series of islands in the river across which a number of crossings took place. One small unnamed island was part of the ford, and downstream there are also Grove Island and Yellow Island.

\section{The Archaeological Study}

The Oldbridge Estate includes the locations of most of the main crossings used on the day of the battle, and also those which saw the most intense fighting and so offered significant potential for archaeological data on the battle. The main focus, which emerged at a relatively early stage of the study, was the identification of the first major engagement of the day, which took place on the southern side of the river following the successful crossing of Oldbridge ford by three battalions of Dutch Blue Guards. A second focus was to identify the location of Oldbridge village, which appears in contemporary depictions of the area and played an important role in the events on the day of the battle.

The study falls into three distinct phases. Phase I was primarily background research involved cartographic and archival research, museum research and assessment of existing aerial photographic coverage. Phase II involved the application of a range of archaeological techniques. This included walkover survey of the estate and systematic surface collection survey of suitable areas, a geophysical survey of the river and an intensive survey of the riverbank, and terrestrial geophysical survey of selected areas totalling four hectares within the estate. Metal detector and soil phosphate surveys of selected areas were also conducted. Phase III involved limited test excavation to verify and further explore the nature of some of the previously collected archaeological data. All work was carried out in accordance with (and where required under licence) the National Monuments Act (1930-1994).

\section{Phase I Work}

As part of Phase I, a number of cartographic archives and museum collections and aerial photographic coverages of the area were examined. Data gathered during this phase was used as the basis for the construction of a GIS (ArcView) model of the study area. 


\section{Aerial Photographic Coverages}

Available aerial photographic coverages of the area were consulted to assess the current and possible past appearance of the battlefield: its morphology, drainage and vegetation. It was hoped to add significantly to our understanding of the location of former field-boundaries and other levelled archaeological features. Three sets of aerial photography were acquired for use in the study. The first was a series of low altitude (ca. $300 \mathrm{~m}$ ) colour oblique shots taken by the planning consultants to the estate development project (Brady Shipman Martin). The second and third sets were high altitude black and white photographs taken by the Ordnance Survey of Ireland (OSI) during the dry summer of 1995. The second set was a series of enlargements of the original images and were produced at a scale of approximately 1:5,000. The third set was a series of six digitally rectified ortho-photos and were used as the basis of the Geographic Information System (GIS).

All photographic coverages used were useful, but the set of enlargements proved to be the most productive. Because of the prevailing conditions at the time they were taken, many otherwise invisible and previously unrecognised low-visibility archaeological features were discernible in the photographs. The most intriguing of these were located in the area adjacent to the gatehouse of Oldbridge House and the ford where the first crossing on the day of the battle took place, and it was hypothesised that some of these features may have been related to the location of the village of Oldbridge.

\section{Geographic Information System (GIS)}

GIS systems are increasingly being used for archaeological research and resource management, especially where research takes place at a landscape scale (see for example Chapman 2006; Gregory 2003; Synnott 1996). As already outlined, the basis of the GIS model used for the Battle of the Boyne survey were the six digitally-rectified OSI ortho-photos covering the full extent of the Oldbridge Estate. From this, separate layers of information were extracted and mapped. These included extant and remnant field boundaries, buildings, roads, trackways, canals, the river, streams, fording points. Digital Sites and Monuments Record (SMR) data, created by the National Monuments Service and data from a previous environmental impact study of the estate, were also included at this stage (Condit 1992). Features and sites of all dates identified during the fieldwork phases of the work were added to this database and all survey data collected (see below) were geo-referenced with Irish National Grid coordinates and were imported directly into the GIS. This approach allowed the data collected to be directly integrated with existing datasets for the area. 


\section{Archival Search}

An extensive programme of archival research was undertaken, although it should be stressed that this element of the study was not exhaustive. While the sources identified were informative, these were predominantly 19th century in date and gave little direct information on the contemporary landscape of the battlefield. The earliest map is the Ordnance Survey Fair Plan of Donore Parish, dating to 1834 . However, a reference to the existence of an estate map dated to 1711 , just 21 years after the battle, was identified. While the original was not located, it is probable that this represents a vital historical source in that it probably depicts the battlefield landscape prior to the reorganisation of the estate lands in the mid-18th century.

\section{Recorded Finds}

The National Museum of Ireland (NMI) holds a substantial collection of objects that relate to the Williamite Campaign in Ireland. However, of these, only one object, an iron cannonball found near the Obelisk Bridge at Oldbridge in 1860, is recorded as coming from the site of the battle. The Louth County Museum also has a small privately-owned collection on display, including three cannonballs which were acquired privately at the auction of the contents of Oldbridge House in 1984 and presumably came from the Oldbridge Estate. The Old Drogheda Society museum at Millmount, Drogheda also has a small collection of artefacts which were donated at various times during the 1960s and 1970 s by local landowners. The NMI also has information on three further collections held privately, which were acquired either at auctions or from dealers or illegally through unlicensed metal detecting. One of the major problems with all of these collections is the almost total lack of provenance information - being limited in most cases to 'Battle of the Boyne battlefield'. A further complicating factor is the possibility of ascription of objects to the site of the Battle of the Boyne in order to add interest or value (Robert Heslip, pers comm). On this basis, a cautious approach must be taken to information relating to finds purporting to come from the battlefield. However, it has been possible during the present survey to verify by archaeological research the veracity and accuracy of information associated with one metal-detected assemblage. It is also likely that as the numbers of finds in the collections discussed here are restricted, significant amounts of material collected by a variety of means over a long time period are still in private possession and remain unrecorded. 


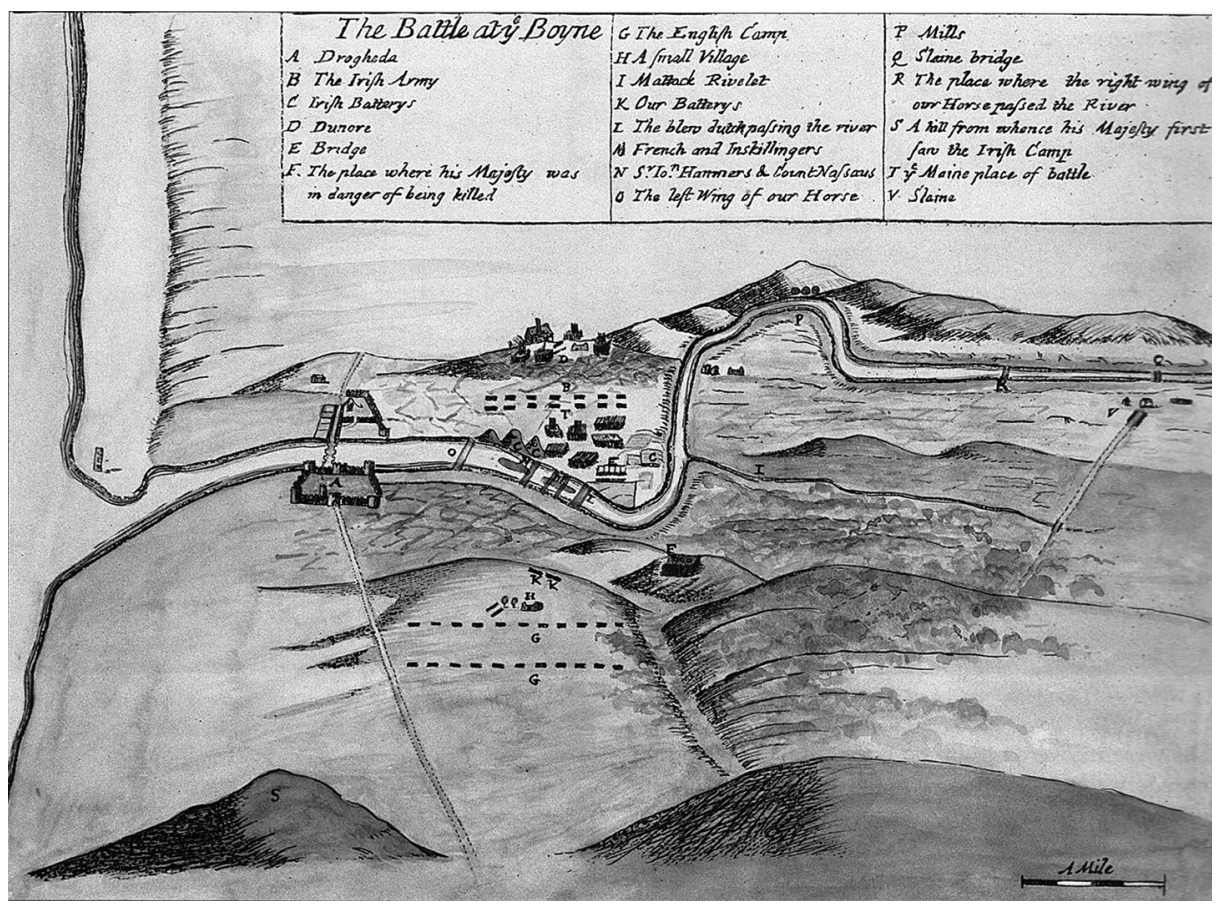

Plate 1. Story's Map.

\section{Additional Historical Sources}

A contemporary map of the battlefield was drawn up by the Reverend George Story, chaplain to William's army (Plate 1). At first glance, this appears to be a schematised sketch map but on closer inspection, and as the study progressed, much of the detail contained within this depiction was confirmed. Of particular interest was the depiction of Oldbridge village, which Story portrays as a row of structures with associated plots or enclosures aligned eastwest along a street or road. The eastern end of the village is shown adjacent to the actual ford of Oldbridge (Stout 2002: 113-17).

Other contemporary depictions of the battle survive today; the majority of these were painted by Jan van Wyck, the most renowned war artist at the time, and it is his images of the battle that are best known. However, the depictions produced by Theodor Maas who was employed by William to record images of his campaign in Ireland are of particular value as an historical source (Plate 2). Indeed, an engraving of the battle by Maas carries the description: 'Designe sur le lieu, le I juillet 1690, par Theodor Maas, peintre du Roy Guillaume'. The landscape is depicted very accurately by Maas, with 


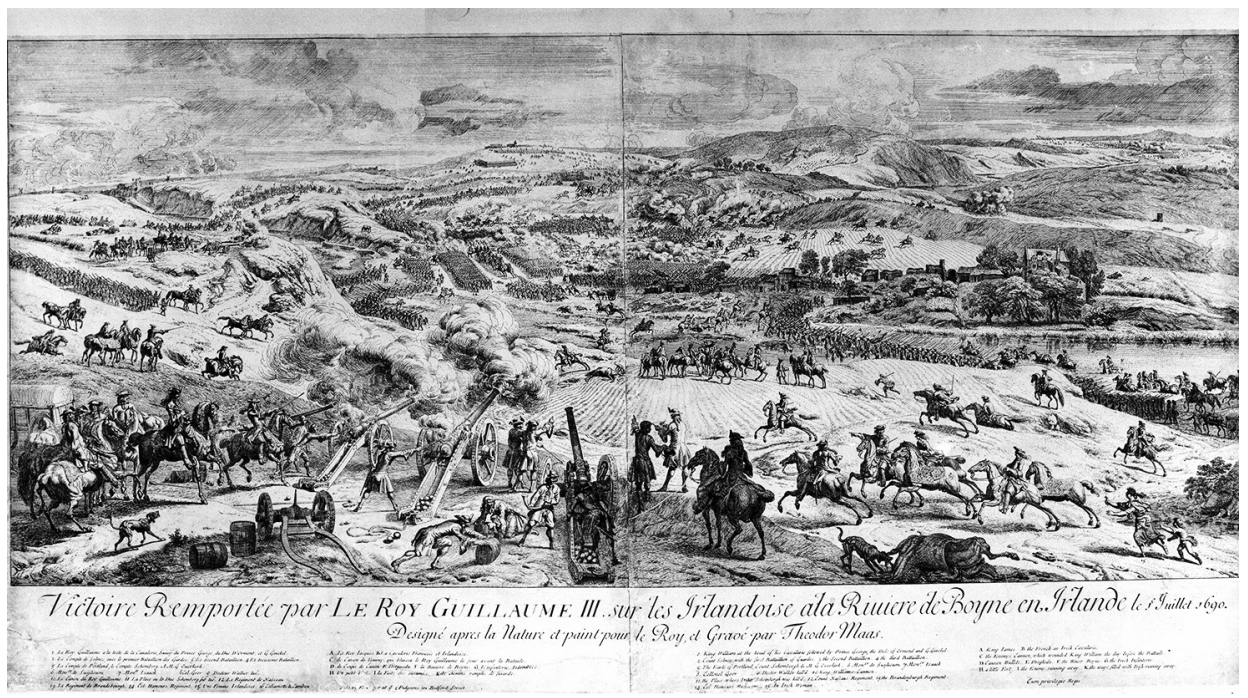

Plate 2. Maas' engraving.

significant detail relating to Oldbridge village that is mirrored almost exactly by the information contained within Story's map. Jan van Wyck produced images giving an artistic interpretation rather than an accurate depiction and it seems quite likely that he based his work on Maas' original, as the two artists use virtually the same composition (Crookshank \& Knight of Glin 1978: 54, plate 36; Harrington 1990).

Also undertaken at this stage was a programme of liaison with a number of military history experts, members of the Military History Society of Ireland, which culminated in a series of walkovers of selected portions of the battlefield. Local landowners were also contacted to inform them of the work and to avail of their local knowledge. It was also hoped that previously unrecorded artefacts might come to light during this exercise.

\section{Phase II Work}

The main aims of this aspect of the work were to establish on the ground the locations of the major physical features that are mentioned and described in the accounts of the battle, especially the remains of Oldbridge village. While the village does seem to have played a role in the events on the day, it did not feature on any of the later maps consulted, so it seems that it had been abandoned and/or removed some time after the battle. 


\section{Walkover Survey}

The full extent of the estate was walked, identifying the locations of known monuments and looking for other low visibility features. Particular attention was focused on the area around the gate lodge and avenue leading to Oldbridge House, as this was the area that appeared from the aerial photographs to be the most likely location of the village.

This area is particularly rich in low-visibility features and the principal ones discernible are two trackways. The first is quite substantial and is of a form of considerable antiquity, a 'double-banked roadway'. It is well constructed, with a central metalled surface and a bank and ditch on either side. It now has a row of trees on either side, probably from the period of emparkment. It runs in a north-south direction and is orientated on the ford. It extends for ca. $400 \mathrm{~m}$ along the eastern edge of the parkland and a further $500 \mathrm{~m}$ along the boundary of a field to the south to link up with a still-used farm track. The second trackway, ca. 2 m wide and comprised of highly compacted gravel, is still visible in the parkland. It runs east-west and seems to correspond with the general location and orientation of Oldbridge village from Story's and Maas' depictions, although it was probably a back-lane on the southern side rather than the main street of the village, which may have been where the more modern avenue of Oldbridge House is now positioned. The two tracks meet immediately south of the ford in the area of the so-called 'Schomberg Stone' which is engraved with the legend '1690', and is traditionally regarded as the spot where Count Schomberg, a Williamite general, was initially buried in the immediate aftermath of the battle before being removed for burial in St Patrick's Cathedral, Dublin. The east-west track and other features appear to extend from the eastern edge of the parkland at least as far west as the farmyard. There is a third trackway running parallel to this leading westward from the main gate past the farmyard towards the northern side of Oldbridge House which may have functioned as a back lane on the northern side of the village.

A survey grid was established over this area with additional panels located in other parts of the estate (Figure 2). Panels A, B and C were positioned to cover the putative area of the village and follow the line of the east-west trackway. Panels D and E were positioned in the field immediately to the east of this, which seemed to be the location of the first engagement of the battle. Panel $\mathrm{F}$ was positioned to examine features that showed up on one of the aerial photographs and Panel $G$ was positioned to examine evidence for activity or movement across this area related to the battle. Much of the subsequent fieldwork focused on one or other of these survey panels. 


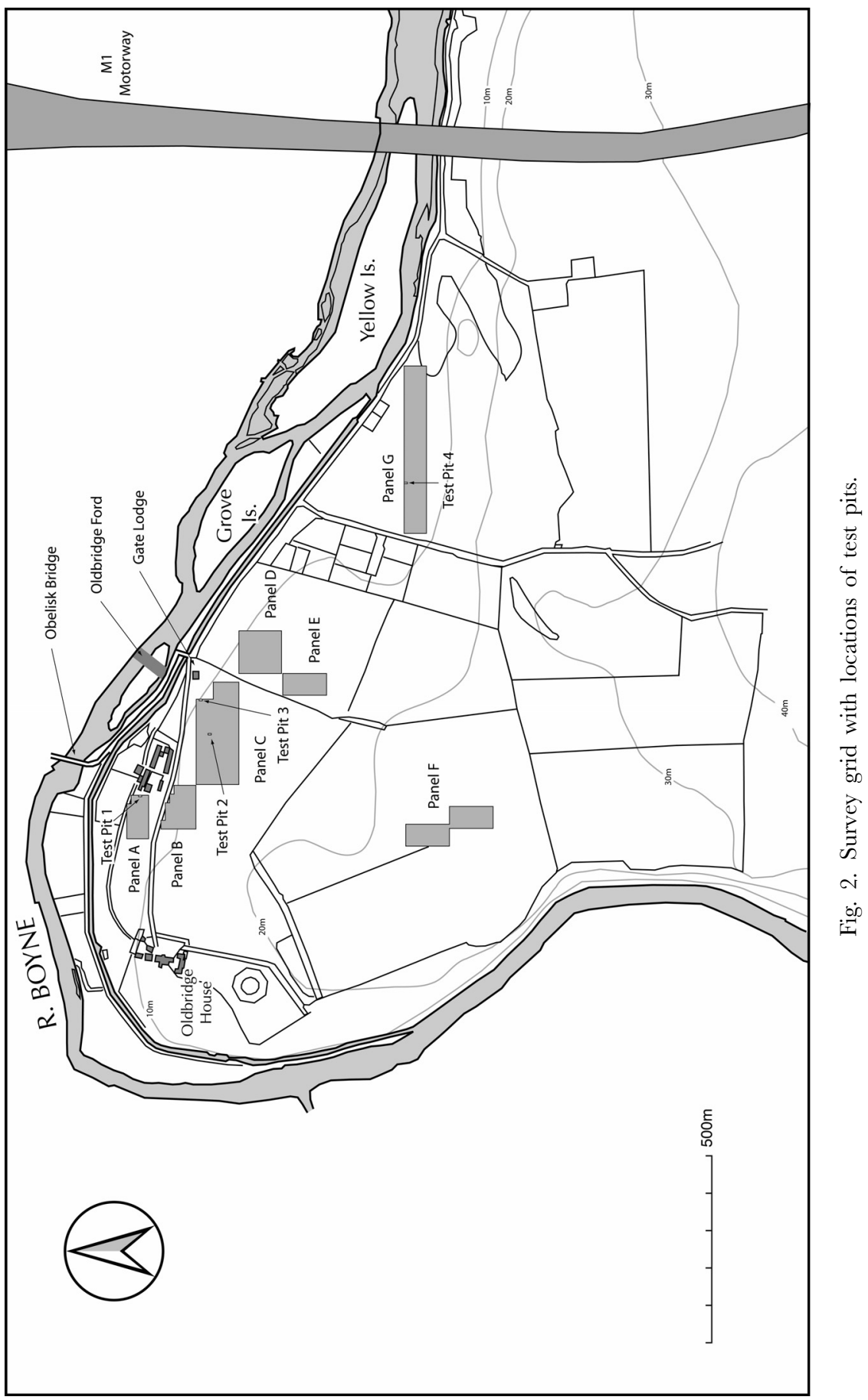




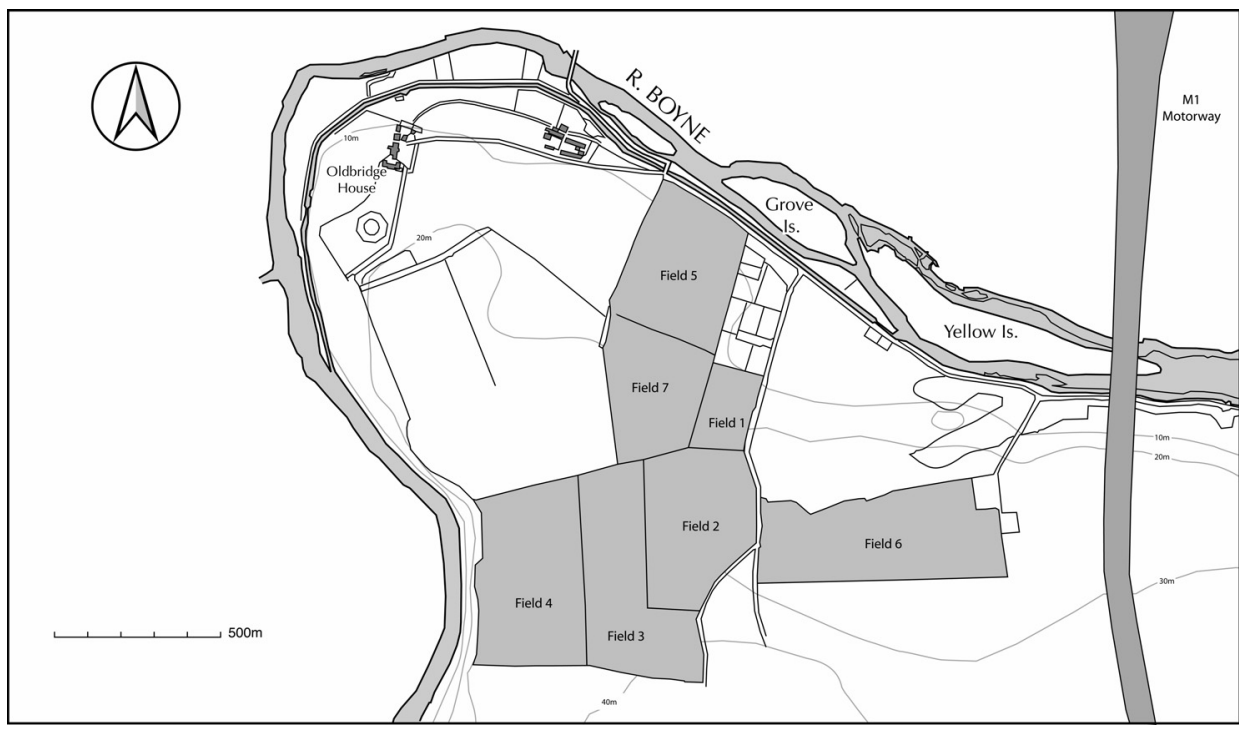

Fig. 3. Extent of fieldwalking survey.

\section{Surface Collection Survey}

The next component of fieldwork involved systematic surface collection survey - a technique ideally suited to the recovery of artefacts within a tilled landscape (Bintliff et al. 2000; Sullivan 1998; Schofield 1991; Haselgrove et al. 1985; Shennan 1985). It is normally used to identify long-term prehistoric settlement and landuse in relation to lithic artefacts, but it can also be useful in the recovery of other durable artefacts which have over time become incorporated into the ploughzone. The technique was used here to identify locations where battle-related material might have been deposited.

The methodology chosen was similar to that of many other Irish surface collection surveys for comparative purposes (Brady 2007; Kimball 2000; Cooney 1990). Parallel transects were walked across each field spaced $10 \mathrm{~m}$ apart. A walker can effectively scan a corridor ca. $2 \mathrm{~m}$ wide along the line of each transect which means that a $20 \%$ sample of the entire surface of the field was directly examined. In total, seven (1-7) tilled fields were systematically examined, spanning the entire width of the estate (Figure 3).

Prehistoric, Medieval, post-Medieval and modern artefacts were recovered. The prehistoric material is exclusively made up of over seven hundred pieces of chipped stone, primarily pebble flint, and the density of this material is significant and is best understood in relation to its proximity to the prehistoric landscape of Brú na Bóinne. More modern material consisted primarily of pottery sherds, which has been interpreted as indicating manuring 
activities. A small but significant number of battle-related finds was also recovered. These came from Fields 4, 5 and 6 . Field 4 produced a gunflint, Field 5 produced five lead shot, a gunflint and an iron buckle or harness fitting and Field 6 produced a half-ecu silver coin (Louis XIV-dated 1659).

Although this might appear to be a small collection a number of points set this material apart from the other finds purportedly from the battlefield. They were the first systematically recovered artefacts from the site of the Battle of the Boyne and represent only a small proportion of what is likely to remain below the surface of each field. They independently corroborate information given to the National Museum of Ireland as to the findspots of illicitly retrieved metal-detector finds. They are of much greater historical and archaeological value than the previously unsystematically recovered finds because they have clear provenances and are the only well-provenanced battle material in state possession. The lead shot from Field 5 support the argument that this is the scene of an engagement, probably the initial one involving the Dutch Blue Guards, among William's best trained and equipped contingents under Count Solms (McNally 2005: 49-50; Murtagh 2006: 39). The two smaller lead shot measured on average $15 \mathrm{~mm}$ in diameter and weighed $17.9 \mathrm{~g}$. Given their size, it appears that they were fired from a pistol. The three larger lead shot measured on average $18 \mathrm{~mm}$ in diameter and weighed $32.5 \mathrm{~g}$ ('8 gauge' shot), and were probably fired from muskets. One of these still retains a portion of the sprue left after casting, while another was somewhat deformed, suggesting that after being fired it had struck an obstacle (St John Hennessy 2004: 529, table 6.13:2). The coin from Field 6 is also important. It is a silver halfecu of Louis XIV, of a type known as à la méche longue and it is possibly the property of a French soldier sent to aid the Jacobite Army (Robert Heslip pers comm). Given its location, it may either have been lost prior to the battle, as it comes from an area where the Jacobite forces were encamped, or was lost during fighting.

Surface-collected artefacts only represent a small sample of the total number of artefacts contained within the ploughsoil. Hence, these finds point to significant assemblages within the ploughzone of the battlefield. At any one time it is estimated that finds visible on the surface of a ploughed field can represent as little as $2 \%$ of the total ploughzone artefact population (Clarke and Schofield 1991). A walker can cover a corridor ca. $2 \mathrm{~m}$ wide with each traverse of a ploughed field resulting in a surface sample of approximately $20 \%$. Thus the four lead shot recovered from Field 5 could represent a total population of up to 1,000 lead shot in the ploughzone here. 


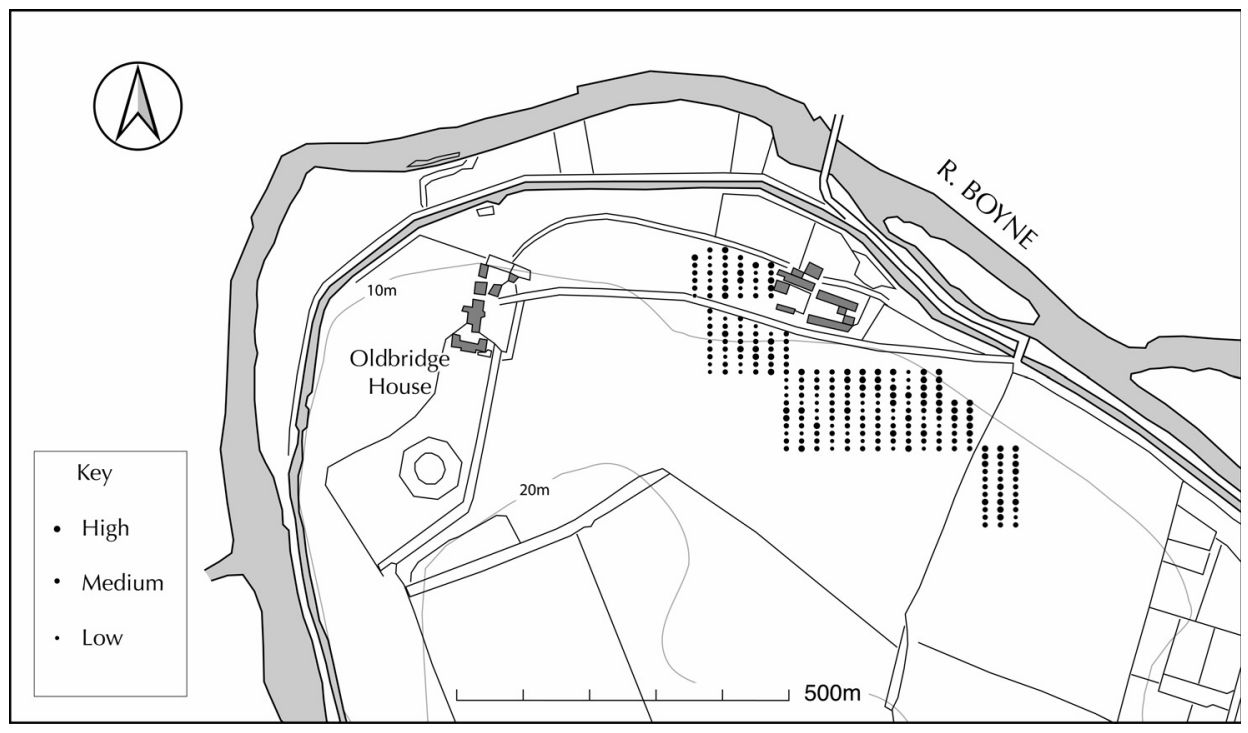

Fig. 4. Phosphate survey results.

\section{Phosphate Survey}

In the area suspected as being the location of Oldbridge village a range of techniques was used including soil phosphate analysis, magnetic gradiometry and metal detecting.

Even where there are no physical traces above ground, past human activity in an area may be indicated by the chemical composition of the soil. Phosphorous $(\mathrm{P})$, in the form of phosphate, is particularly useful in this regard. It accumulates rapidly in the vicinity of human settlements and burials as a result of the deposition of manure, faeces and other organic materials. Unlike many other chemicals deposited in similar ways, it can remain stable in most soil types for thousands of years. Using an appropriate soil sampling strategy and chemical test, enhanced phosphate levels can be detected and patterns of human settlement and activity delineated (Magee 1997; Hammond 1985). We carried out this work over the suspected area of the village to help confirm the nature of the low-visibility features.

The methodology involved taking soil samples from below the level of disturbance by ploughing and at an average depth of $350 \mathrm{~mm}$ with a $10 \mathrm{~mm}$ augur at 10 by $20 \mathrm{~m}$ intervals across the survey grid. This strategy minimises natural variations in phosphate and screens out the masking effects of modern disturbance and enhancement through manuring, which primarily affects topsoil levels. Samples were taken in Panels A, B, and C and also in D. These 
were analysed using a 'field test' method, which indicates the relative quantity of phosphate present as being either 'high', 'medium' or 'low' rather than in absolute terms (Hammond 1985). As can be seen from the plot the distribution of higher values is clustered around the area of the village. More specifically however, there is a marked concentration of high values in Panel C indicating intense human activity, most likely prolonged settlement (Figure 4).

The plot of phosphate levels clearly shows a degree of variability over the surveyed area. The majority of the readings were either medium or high because of the relatively high background phosphate levels in this part of Co Meath (Cyril D'Arcy, pers comm). This reduced the scope for clear definition between areas of enhanced phosphate and those that were less enhanced, but patterning was nonetheless visible. There is a cluster of high values around the extant farmyard and a marked concentration in the north-east corner of Panel $\mathrm{C}$ that stand out in clear contrast to a series of low values distributed along the line of the east-west gravel trackway. The medium and high values in Panel D are more difficult to interpret as it was found that the ploughsoil was unusually deep in this area, reaching depths of between $0.5 \mathrm{~m}$ and $0.6 \mathrm{~m}$. The values recorded here may be the result of modern agricultural practices, or the deep ploughing may have disturbed and masked any pre-existing patterns, giving rise to the relatively homogeneous distribution of values.

The defined area of high values in the north-eastern corner of Panel C indicates intense human activity. Taken in conjunction with other strands of evidence, it seems highly probable that these values indicate the location of at least part of Oldbridge village, one of the primary foci during the Battle of the Boyne.

\section{Geophysical Survey}

Magnetic gradiometry survey was carried out on and covered almost four hectares in total, spread over five separate panels (Gaffney and Gater 2003: 61-4). The objectives were to locate and identify potential sub-surface archaeological features generally, to locate and identify potential sub-surface archaeological features related to the battle and to locate direct evidence for Oldbridge village.

A significant number of anomalies were recorded during this survey (Figure 5; McCarthy 2001). Features such as the gravel trackway, ditches (one of which contained burnt material), a small hearth or furnace, a small field system and a large field system as well as other possible field boundaries and enclosures, were identified. In addition, there was at least one structure with a concentration of metal objects and debris around it, and possibly two others. These, along with another area identified on aerial photographs have been interpreted as houses. 


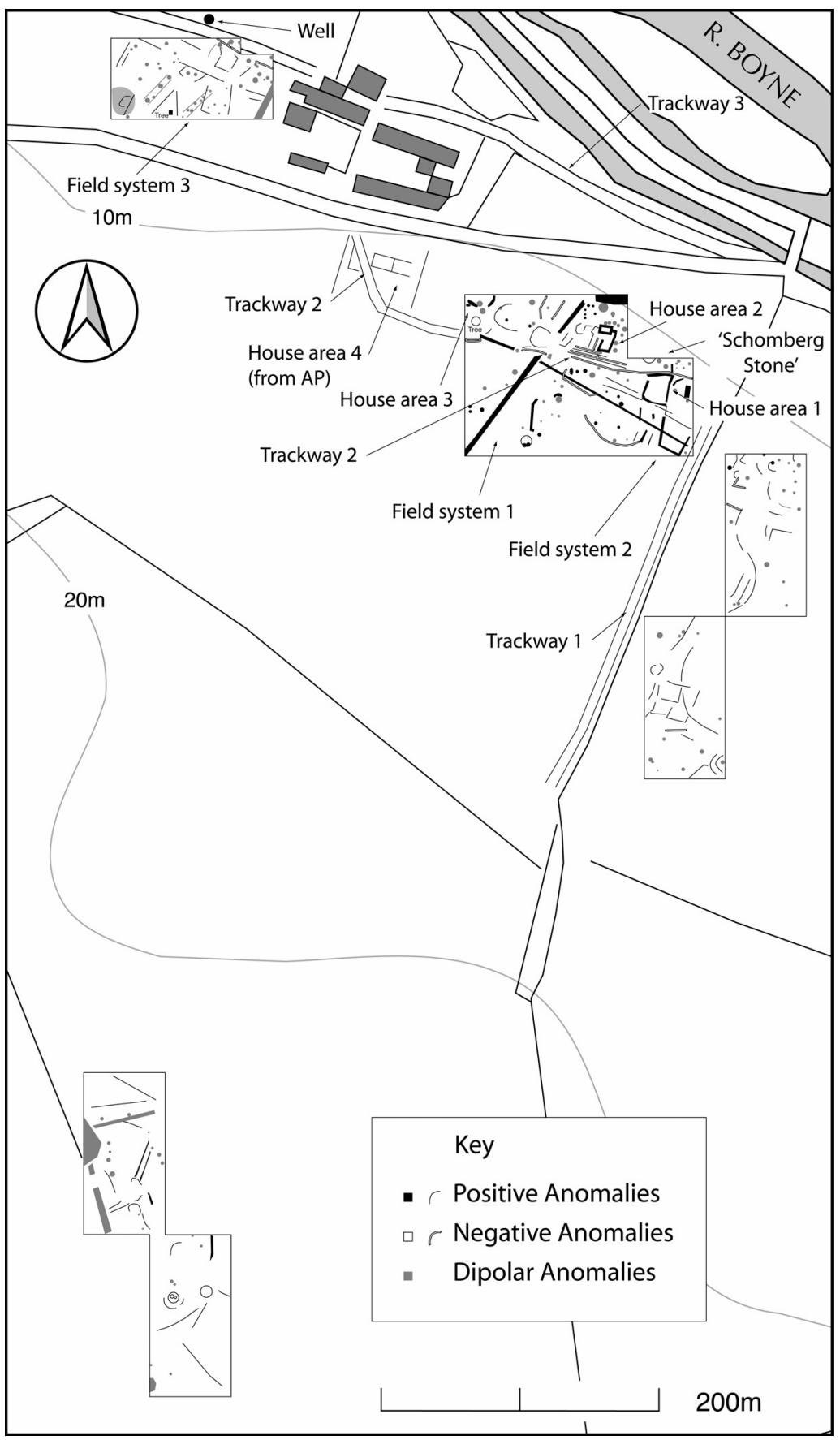

Fig. 5. Magnetic gradiometry survey interpretative plots. 
The first and least conclusive area identified, House area 1, is located immediately adjacent to the 'Schomberg Stone'. Although there are no clear foundations visible, the number and pattern of dipolar anomalies, probably indicative of buried iron objects, is very similar to those found at the other two houses and its proximity to a field system suggest that this is possibly a house area. House area 2 lies $30 \mathrm{~m}$ to the west. The structure appears to have been $7 \times 4 \mathrm{~m}$, orientated east-west, similar to what is depicted in Maas' illustration. This has a yard area $19 \times 13 \mathrm{~m}$, with gaps or a possible entrance along the southern side. The concentration of dipolar anomalies to the north of the house may have been related to activities carried out during the occupation of the house, or to the decay of the roof, or to the structure being the target of intense musket or even cannon fire during the battle. The largest dipolar anomaly probably represents a hearth and supports the interpretation of day-to-day small-scale settlement and agricultural activity.

House area 3 lies $68 \mathrm{~m}$ further to the west of House area 2. It consists of two small arcs, possibly foundation trenches, with a few associated dipolar anomalies. These features enclose an area of approximately $13 \times 11 \mathrm{~m}$ and probably represent a yard area. House area 4 was identified solely on the basis of examination of aerial photographs, but is presented here for completeness. It appears to be a structure ca. $22 \times 8 \mathrm{~m}$, orientated east-west. It is located in the middle of a small field ca. $58 \times 32 \mathrm{~m}$.

\section{Metal Detecting}

Metal detecting was carried out as an ideal technique to identify scatters of material that might be associated with the battle. Although frequently the recipient of unfavourable comment due to associations with illicit treasurehunting activities, this technique has been productively applied with best practice in a number of archaeological projects, particularly in the United States and Great Britain (Carman 2001).

Metal detecting was used during this survey as a prospecting tool rather than for the recovery of artefacts. A Fischer XB 1266 metal detector was the instrument used for the survey. The objectives of this element of the survey were to provide data to help identify the extent of Oldbridge village and to identify concentrations of metal objects that could be associated with the battle. Using the survey grid established across the site, north-south transects at $10 \mathrm{~m}$ intervals were walked across Panels A, B, C, D and G. A ca. $2 \mathrm{~m}$ wide corridor was covered by each pass, representing an approximate $20 \%$ surface sample. In the plots presented here, numbers of 'hits' are illustrated in $10 \mathrm{~m}$ blocks (Figure 6). The distribution of 'discriminant 2' 'hits' was also recorded for each panel where the metal detector was set to filter out ferrous objects with the aim of better identification of possible lead shot (not illustrated). 


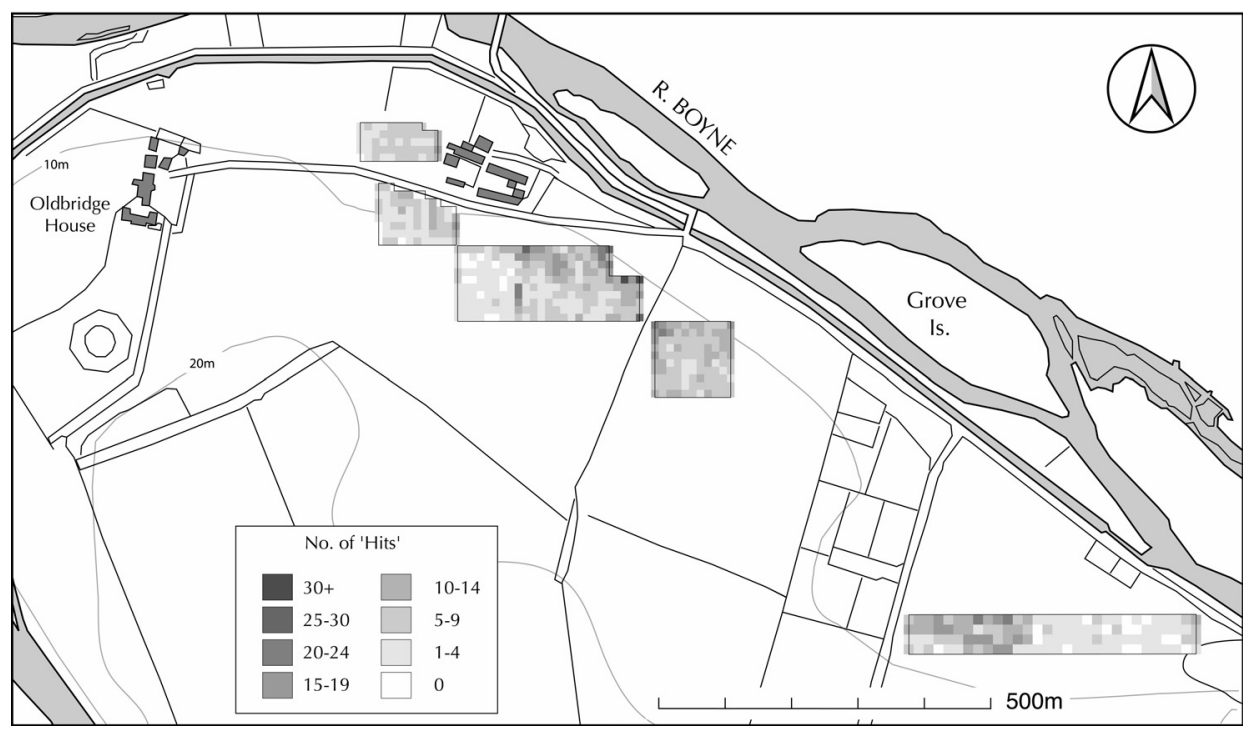

Fig. 6. Metal detector survey results.

The distribution of 'hits' in Panel A increases from west to east, suggesting a concentration of activity at the eastern end of the panel, close to the farmyard. The material may be the result of cumulative discard of material from the farmyard, or it could represent material associated with the western extent of the village, an interpretation supported by other strands of survey data. The distribution of discriminant 2 'hits' generally mirrors the overall distribution.

In Panel B, there was a similar trend in the distribution with 'hits' increasing generally from west to east. There is also an observable trend from southwest to north-east; again, the distribution may be the result of deposition associated with the management of the farmyard or, more likely, it is associated with the occupation of the village. The distribution of discriminant 2 'hits' generally mirrors the overall distribution of hits.

In Panel $\mathrm{C}$, there is a trend from south-west to north-east, with a focus on the area of the raised gravel trackway, but also with some isolated high density areas: one in the centre of the panel and the other in the extreme south-east. The highest density area is around the 'Schomberg Stone', close to a house area (House area 1) identified from the magnetic gradiometry data. The distribution of discriminant 2 'hits' generally mirrors the overall distribution of hits. 
Panel D produced the highest density of 'hits' of all panels investigated; the distribution here is remarkably homogeneous, with a slight concentration of material in the north-western corner. This even spread is thought to have been created by intensity and depth of ploughing in modern times, a feature which was also noted in the magnetic gradiometry survey. The higher density of material in the north-western corner may represent the best evidence of the eastern extent of the village as the depth of ploughing seems to have destroyed any evidence of features in this area. Battle-related material was recovered from this field during the surface-collection survey (Field 4) and also by treasure hunters, so a proportion of these recorded 'hits' must be viewed as probably corresponding to material associated with the battle. Discriminant 2 'hits' represented $44 \%$ of all 'hits' from the panel, the highest proportion of all of the panels and the distribution mirrors the general distribution.

Panel G was positioned in a field where there appears from Story's map to have been two Jacobite artillery pieces positioned at the eastern end (Col. Donal O'Carroll, pers comm). There is a concentration in the western half of Panel $G$, with a minor concentration to the east of centre and another at the north-eastern corner. The eastern edge of the concentration at the western end of the panel seems to coincide with the location of a remnant field boundary, which possibly originally enclosed an orchard marked on the 1834 Fair Plan. The smaller concentration at the north-eastern corner corresponds with the location of a covered well that is extant and which is also marked on various maps. The distribution of discriminant 2 'hits' is broadly similar to the overall distribution of hits.

Panel D had the highest density of 'hits' overall, and there appears to be a gradual decrease in density moving westwards across Panels C, B and A respectively. The densest areas of 'hits' were found to be in the northern portion of Panels C and D and seem to correspond well to other strands of evidence that indicate this as the location of the village. The pattern of discriminant 2 'hits', indicating higher-grade metals than iron, is broadly reflective of the overall distribution of all metal hits. There were a number of slight deviations from this general trend, possibly indicating battle-related activity. It was assumed that battle-related activity might produce a scatter of material with a higher proportion of discriminant 2 'hits' because of the large amount of lead shot that would have been used. The highest proportion of discriminant 2 'hits' came from Panel D which is located in a field from which five pieces of lead shot were recovered during the surface collection survey (Field 5) and where a significant amount of other battle-related material was recovered by treasure hunters. This and other evidence points to this area as being the 
location of the fiercest fighting on the morning of the battle, probably incorporating the first engagement of the day between William's Dutch foot and the Jacobite infantry and cavalry.

\section{The River Survey}

The Boyne clearly played major role on the day of the battle and needed to be assessed for its archaeological potential. Earlier work in the area had pointed to the potential of material to be preserved in the river (Gregory 1995). Marine geophysics was carried out along most of the length of the boundary of the estate and covered all documented crossing places used on the day of the battle, from Drybridge to the east to the confluence of the Boyne and the Mattock to the west and comprised side-scan sonar and marine proton magnetic gradiometry.

The side-scan sonar survey was used to characterise the nature of the riverbed and locate large debris and features. The identification of 'sediment traps' was a priority in that these are the most likely locations where small finds might have been secondarily deposited and represent the best areas on which to focus any future diving activity. The marine proton magnetic gradiometry was carried out to locate areas of accumulated metal objects. Several anomalies were isolated and could form the basis of more specific work in the future (Boland 2001).

The riverine geophysical surveys provided important base-line data setting the foundation for all future work. The locations of the fords were clearly established as were locations where future dives should be best positioned.

\section{New Light on the Crossing Places}

Previous researchers have relied on Story's map for the locations of the crossing places used during the battle. However, the aerial photographic evidence, the river profiling undertaken as part of this study and other recent underwater investigations in the area provide new information. From the aerial photographs, it is clear that areas of shallows only loosely correspond to the crossing points indicated by Story. While the river channel and the upstream and downstream ends of the islands appear to have been altered in the time since the battle, the shallows themselves are unlikely to have been substantially displaced.

It is accepted that the first crossing took place at the ford of Oldbridge. However, it is suggested here that, although Story's map suggests that the second crossing took place across Grove Island, it is likely to have taken place beyond the western end of Grove Island as it exists today, across a small islet depicted on the first and second editions OS maps which is now partly eroded away and partly incorporated into the southern bank (Figure 7). Drainage 


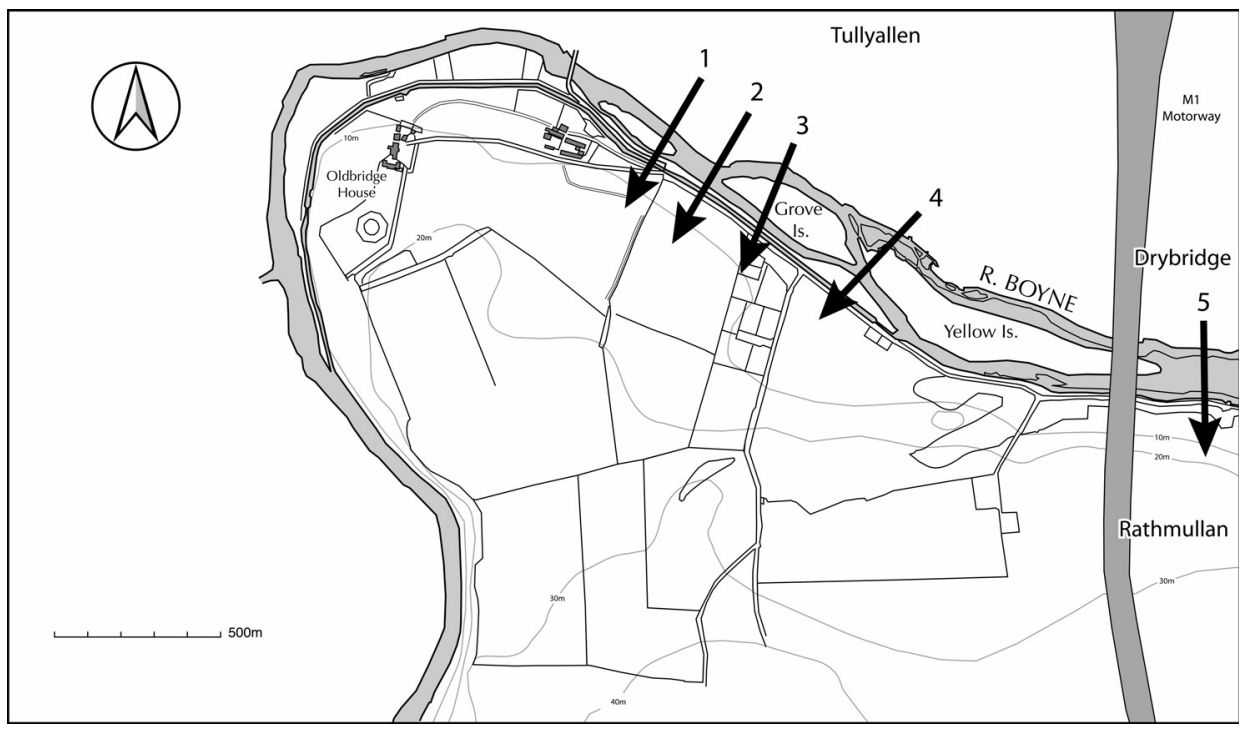

Fig. 7. Locations of main crossings.

works upstream in the 19th century and dredging downstream in the 20th century have greatly increased the rates of erosion and deposition along the river. The third crossing may have been more or less where it is depicted on Story's map, but given the actual location of the shallows in this area, it is likely to have been a little further to the west. The fourth crossing probably took place where it is depicted by Story, across the western end of Yellow Island. The location of the fifth crossing at Drybridge remains unchanged and new information has recently emerged regarding the location, extent and profile of a large inter-tidal mud bank in the middle of the river from an underwater archaeological survey (Brady \& Bolton 2001: figure 3).

\section{Phase III Test-Pit Excavations}

A targeted excavation programme was undertaken with the digging of four test pits in order to verify, qualify and ground-truth the results of the three non-invasive terrestrial surveys, particularly the metal-detector survey. They were dug to the surface of archaeology only, in accordance with the project brief. Each pit measured $2 \times 1 \mathrm{~m}$ and all spoil was passed through a $5 \mathrm{~mm}$ mesh sieve. For locations see Figure 1.

Test Pit 1 was located at the eastern end of Panel A to the west of the farmyard to investigate the high densities of metal-detector 'hits' recorded here. Finds included early to mid-18th century blackware pottery, several iron 
nails and pieces of wire, ceramic drainpipe fragments and a Medieval quartzite plough pebble (see Brady 1988). Test Pits 2 and 3 were in Panel C. Test Pit 2 was positioned on the gravel trackway and produced evidence of a wheelrut, with just one find: an iron staple, although there was evidence from the metal detector data that there were further metal objects contained within its matrix. Test Pit 3 was positioned near to the 'Schomberg Stone' in the northeastern corner of Panel $\mathrm{C}$ and produced a high density of material including blackware pottery, white-glazed pottery, fragments of red brick, a piece of slate, fragments of animal bone and a flint flake. Metal finds include a fragment of iron plate, a metal staple and two pieces of wire. Test Pit 4 was located in Panel G in the Groggin's Field to investigate a high density area of metal detector hits. Clear evidence of cultivation furrows was encountered and fifteen small iron nails, blackware, brownware and white-glazed pottery, brick and mortar fragments, sea shell fragments, animal bone, coal, cinders and a flint scraper were recovered. There was a considerable depth of cultivation soil in this area, in excess of $0.5 \mathrm{~m}$, indicating that this was probably area where extensive deposition of soil from elsewhere took place. This soil contained large quantities of domestic and building material and was probably related to the establishment of an orchard in this area as depicted on the 1834 OS Fair Plan.

While this programme was limited in scale, it did provide useful clarification. Test Pits 1 and 3 produced clear evidence of settlement in the form of habitation/farmyard detritus and Test Pit 3 in particular produced the clearest evidence of the former presence of formal structures within the area of the village as indicated by the phosphate and magnetic gradiometry surveys. An earlyto mid-18th century date was indicated by some of the pottery (Orser 2000), which may relate to the final stages of occupation of the village, while later finds may relate to deposition generated by activities related to the farmyard. Test Pit 2 validated the nature and function of the gravel trackway. Test Pit 4 indicated that the concentration of metal detector 'hits' in that area was due to ground being raised by up to $1 \mathrm{~m}$ probably to level the area at the time of the setting out of the orchard which is depicted on the OS Fair Plan.

\section{Conclusion}

This survey was designed as a pilot assessment of the archaeological potential of the Oldbridge Estate with specific reference to the Battle of the Boyne. It has produced a number of important results. An archaeological profile of the estate has been produced, documenting activity from at least the Neolithic to the 20th century, much of which was previously unknown. Key areas in 
the battlefield of the Battle of the Boyne have been unequivocally identified for the first time. These include the location of Oldbridge village, the scene of the first engagement of the battle, and the key fording points across the river. The first systematically recovered and best provenanced material relating to the battle was recovered during the survey. An additional key feature of the area is the extensive survival of the 18th century estate landscape (Stout 2002: 132-34, fig. 15).

The river survey was also very successful, demonstrating the value of using marine equipment in a river environment and highlighting areas of potential for future work. All of this work has implications for the interpretation of the battle, but it also provides a baseline for the direction that future research could take as part of the management and presentation of the battle. This might include work such as targeted diving in the river, a combined detailed topographic survey and extension of the geophysical survey in the area of the village to establish its extent, followed perhaps by excavation aimed at elucidating the character of the settlement and its role during the battle. Systematic large-scale metal detector survey across the full extent of the estate would identify further areas of potential. In addition to this, of course, the Oldbridge Estate is only part of the battlefield. Further work could usefully take in the wider landscape, especially those areas that are known to have figured in the battle, such as the Hill of Donore and Platin. The key and sensitive question of the burial places of the casualties of the day, if they exist, also needs to be addressed.

\section{Acrinowledgements}

This paper results from work carried out under contract to Dúchas, The Heritage Service and we are very grateful to the Office of Public Works for permission and support to publish this work. Our thanks to Eugene Keane (O.P.W.), Aisling MacMahon (O.P.W.), Col. Donal O'Carroll (Military History Society of Ireland), Harman Murtagh (Military History Society of Ireland), Donal Boland (Management for Archaeology Underwater), Rory McNeary (Management for Archaeology Underwater), Martina McCarthy (GeoArc Ltd.), Joe Fenwick (N.U.I. Galway), Robert Heslip (Ulster Museum), Geraldine Stout (Department of the Environment, Heritage and Local Government), Eamonn P. Kelly (National Museum of Ireland), Cyril D’Arcy (Teagasc, Drogheda) and Breeda Tuite.

\section{REFERENCES}

Beresford Ellis, P. 1976: The Boyne Water: The Battle of the Boyne 1690. The Blackstaff Press: Belfast. Bence-Jones, M. 1978: Burke's Guide to Country Houses. Volume 1-Ireland. Burke's Peerage: London. Bintliff, J. L., Kuna, M. \& Venclová, N. (eds.) 2000: The Future of Artefact Survey in Europe. Sheffield Academic Press: Sheffield. 
Boland, D. 2001: Boyne River Archaeological Assessment, Oldbridge. Report for University College Dublin. Management for Archaeology Underwater Ltd. (appendix II in Cooney et al. 2001). Brady, C. 2007: A Landscape Survey of the Newgrange Environs: Earlier Prehistoric Settlement at Bru na Bóinne, Co Meath. Unpublished PhD Thesis, School of Archaeology University College Dublin. Brady, N. 1988: 'The Plough Pebbles of Ireland', Tools \& Tillage 6, 47-60.

Brady, N. \& Bolton, J. 2001: Underwater Archaeological Assessment of the River Boyne at Oldbridge, Co. Meath. Unpublished archaeological report. Valerie J. Keeley Ltd.

Carman, J. 2001: 'Rules of engagement', Antiquity 75, 191-93.

Chapman, H. 2006: Landscape Archaeology and GIS. Tempus: Stroud.

Childs, J. 1996: 'The Williamite war, 1689-1691', in Bartlett, T. \& Jeffery, K. (eds.) A Military History of Ireland, 188-210. Cambridge University Press: Cambridge.

Condit, T. 1992: 'The Cultural Heritage' in Environmental Impact Study for Oldbridge House. Dublin: Environmental Impact Services Ltd.

Cooney, G. 1990: 'The Mount Oriel Project: an introduction', County Louth Archaeological and Historical fournal, 21, 123-39.

Cooney, G., Byrnes, E., Brady, C. \& O’Sullivan, A. 2001: A Pilot Archaeological Study of the Site of the Battle of the Boyne, Oldbridge Estate, Co. Meath. Unpublished report for Dúchas The Heritage Service. Dublin: Department of Archaeology, University College Dublin.

. 2002: 'The archaeology of the Battle of the Boyne at Oldbridge, Co. Meath', Archaeology Ireland 62, 8-12.

Crookshank, A. \& Knight of Glin 1978: The Painters of Ireland c. 1600-1920. Barrie and Jenkins: London.

Dewar, M., Brown, J., \& Long, S. E. 1969: Orangeism: A New Historical Appreciation. 2nd ed. Belfast: Grand Orange Lodge of Ireland.

Gaffney, C. \& Gater, J. 2003: Revealing the Buried Past: Geophysics for Archaeologists. Tempus: Stroud.

Gibbs, G. C. 1990: 'The European origins of the Glorious Revolution', in Maguire, W. A. (ed.), Kings in Conflict: The Revolutionary War in Ireland and its Aftermath, 1689-1750. 9-28. Blackstaff Press: Belfast.

Gregory, I. 2003: A Place in History: A Guide to Using GIS in Historical Research. Oxbow Books: Oxford.

Gregory, N. 1995: 'River Boyne, Staleen townland, County Meath: excavation report', County Louth Archaeological and Historical Fournal 23, 18-33.

Haddick-Flynn, K. 1999: Orangeism: The Making of a Tradition. Wolfhound: Dublin.

Hamond, F. W. 1983: 'Phosphate analysis of archaeological sediments', in Reeves-Smyth, T. \& Hamond, F. W. (eds) Landscape Archaeology in Ireland. BAR British Series 116, 47-80 Archaeopress: Oxford.

- 1985: 'Chemical analysis of soils', in Woodman, P. C. Excavations at Mount Sandel 1973-33. 83-98. Northern Ireland HMSO: Belfast.

Harrington, P. 1990: 'Images of the Boyne', Irish Sword 70, 57-61.

Haselgrove, C., Millett, M. \& Smith I. (eds.) 1985: Archaeolgy from the Ploughsoil. Department of Archaeology, University of Sheffield: Sheffield.

Kimball, M. Human Ecology and Neolithic Transition in Eastern County Donegal, Ireland, The Lough Swilly Archaeological Survey. BAR British Series 300. Archaeopress: Oxford.

Lenihan, P. 2003: 1690: Battle of the Boyne. Tempus: Stroud.

Long, S. E. 1978: The Orange Institution. Grand Orange Lodge of Ireland: Belfast.

Magee, R. W. 1997: 'Geochemical survey', in Newman, C. (ed.) Tara: An archaeological survey. 285-314. Royal Irish Academy: Dublin.

McCarthy, M. 2001: A Geophysical Investigation at the site of the Battle of the Boyne, Oldbridge, Co Meath. Survey carried out on behalf of the Department of Archaeology University College Dublin. GeoArc Ltd. (appendix 1 in Cooney et al. 2001).

McGuire, J. 1990: 'James II and Ireland, 1685-1690', in Maguire, W. A. (ed.), Kings in Conflict: The Revolutionary War in Ireland and its Aftermath, 1689-1750. 45-57. Blackstaff Press: Belfast.

McNally, M. 2005: Battle of the Boyne 1690: The Irish Campaign for the English Crown. Osprey: Oxford. 
Meehan, R. T. \& Warren, W. P. 1999: The Boyne Valley in the Ice Age: A Field Guide to some of the Valley's Most Important Geological Features. Geological Survey of Ireland: Dublin.

Miller, J. 1990: 'The Glorious Revolution', in Maguire, W. A. (ed.), Kings in Conflict: The Revolutionary War in Ireland and its Aftermath, 1689-1750. 29-44. Blackstaff Press: Belfast.

Murtagh, H. 2006 The Battle of the Boyne 1690: A Guide to the Battlefield. The Boyne Valley Honey Company: Drogheda.

O'Carroll, D. 1990: 'An indifferent good post: the battlefield of the Boyne', The Irish Sword 70, 49-57.

Orser, C. 2000: 'In praise of early nineteenth century coarse earthenware', Archaeology Ireland $54,8-11$.

Schofield, A. J. (ed.) 1991: Interpreting Artefact Scatters: Contributions to Ploughzone Archaeology. Oxbow: Oxford.

Shennan, S. 1985: Experiments in the Collection and Analysis of Archaeological Survey Data: the East Hampshire Survey. Department of Archaeology, University of Sheffield: Sheffield.

Synnott, P. 1996: 'Geographical Information Systems - an archaeological application', Discovery Programme Reports 4, 73-84. Royal Irish Academy: Dublin.

Smyth, J. 1995: 'The men of No Popery: the origins of the Orange Order', History Ireland 3, $48-53$.

St John Hennessy, N. 2004: 'Canon and musket shot', in Fitzpatrick, E., O'Brien, M. \& Walsh, P. (eds.) Archaeological Investigations in Galway City 1987-1998. 527-29. Wordwell: Bray. Stout, G. 2002: Newgrange and the Bend of the Boyne. Cork University Press: Cork.

Sullivan, A. P. (ed.) 1998: Surface Archaeology. University of New Mexico Press: Albuquerque.

Whelan, K. 1996: 'The origins of the Orange Order', Bullan: An Irish Studies Review 2, 19-37. 